\title{
The effectiveness of integrated farm management, organic farming and agri-environment schemes for conserving biodiversity in temperate Europe - A systematic map
}

\author{
Nicola P Randall ${ }^{*}$ and Katy L James
}

\begin{abstract}
Background: Agriculture is the dominant land use throughout much of Europe. Changes to farming practices have led to concerns about negative impacts on biodiversity, and current agricultural policy has an emphasis towards conservation. The objective of this study was to investigate and describe the nature and coverage of research pertaining to the effectiveness of integrated farm management, organic farming and agri-environment schemes as interventions for conserving biodiversity in temperate Europe.

Systematic mapping methodology was adapted from social sciences, and used to create a searchable database of relevant research.

Methods: Searches were made of 10 electronic databases containing peer reviewed journals, PhD theses, conference proceedings and organisational reports. Web searches for relevant research were also made. The title and abstracts of results were examined for relevance. Studies were included when published in English, when an intervention was applied to increase biodiversity or species diversity on farmland, and where there was a measured effect on study organism(s). Correlative and manipulative studies from temperate Europe were included. The research was incorporated into a searchable database (systematic map) and key wording used to describe, categorise and code studies.
\end{abstract}

Results: The searches identified 83,590 records. Following removal of duplicates and the application of inclusion criteria, 743 references were coded for the final systematic map database. Most of the studies reported were from Western Europe, particularly from the UK. Invertebrates were the most commonly studied organism followed by plants and birds, and field margins were the most commonly studied biotope.

Conclusions: The systematic map describes the scope of research on the topic. It can be used to inform future primary research, or research synthesis and evaluation methods such as systematic review. Areas for which there appear to be evidence gaps, and so may have potential for further primary research, are highlighted. They include the effectiveness of agri-environment options under different farming systems and in providing for amphibians and reptiles. Implications for the development of future systematic maps are discussed, including the question of how to incorporate study quality appraisal. The development of a Collaboration for Environmental Evidence systematic mapping methods group will address some of these issues.

Keywords: Farmland biodiversity, Conservation, Systematic map, Systematic review, Agri-environment, Organic farming, Integrated farm management, Evidence-based policy

\footnotetext{
* Correspondence: nrandall@harper-adams.ac.uk

Harper Adams University College, Newport, Shropshire TF10 8NB, UK
} 


\section{Background}

Agriculture is the dominant land use throughout much of Western Europe [1]. It covers about $47 \%$ of total European Union territory [2]. Since the 1940s, farming has become increasingly intensive, resulting in the widespread decline of many farmland species. Declines in farmland birds have been particularly well documented $[3,4]$ but also for other taxa, including mammals, arthropods and flowering plants $[5,6]$. Factors believed to lead to losses include an increase in the use of pesticides and fertilisers, loss of non-crop biotopes, a change from spring to autumn cropping, land drainage, increased stocking densities, switch from hay to silage and an increase in landscape homogeneity resulting from regional specialisation of farming practices [1,7-9]. With an increasing world population one of the major challenges for the future will be how best to meet the need to increase food production whilst minimising the harm to biodiversity [10].

Concerns about harm to biodiversity and the environment have led to a greater emphasis on environmental protection and biodiversity conservation in agricultural policy. This has included new agri-environment schemes that provide payment for management that is designed to be environmentally beneficial [7]. Following a European discussion paper in 1985, which addressed the environmental impact of agriculture [11], agri-environment schemes (AES) have been available to European Union member states under the Common Agricultural Policy [12], and agri-environment is a key European Union policy with 22.2 billion Euros allocated to schemes by member states for the period 2007 to 2013 [13]. However, these schemes are subject to change, and vary between different countries.

A number of studies have examined whether AES conserve or increase biodiversity [12,14 for example], but results appear variable and may be affected by a number of factors. For example AES may provide only some of the resources needed by target organisms, or provision may be inadequately located [15]. Landscape structure may also affect the success of farmland biodiversity initiatives [16]. Changes to future funding initiatives could be made in order to address these issues [15]. The European Commission has recently been carrying out consultations on how best to reform the Common Agricultural Policy, including how best to use future incentives for farmers to deal with environmental concerns such as biodiversity [12].

Wider concerns about the sustainability, environmental impacts and health effects of intensive farming have led to an increased demand for organic food, and development of alternative systems such as integrated farming. Integrated farming aims to minimise the use of pesticides and fertilisers through better targeting, and integration with cultural control of weeds, pests and diseases [7].
The European Commission consider integrated crop management to be of particular importance when combining modern farming with the capacity to ensure good environmental outcome [2]. Both organic and integrated farming may have positive benefits for biodiversity [1720], although results vary between studies and species.

For example, Hole et al. [21] used data from Europe, New Zealand, the US and Canada to suggest that organic farming increased biodiversity at every level of the food chain, yet a meta-analysis by Bengstsson et al. [22] found that results varied between studies, and between organism groups and landscapes. Fuller et al. [23] suggested that the variation between taxa is because organic farms may be too small and isolated to affect species with large spatial needs. Furthermore, a recent study showed that the benefits of organic farming to wildlife and increases in biodiversity are much lower than previously thought [24].

In their recent consultation on reform of the Common Agricultural Policy, the European Commission identified the need to find out how best to protect maintain and enhance farmland habitats and biodiversity throughout Europe [2].

The primary objective of this study was to describe and 'map' research pertaining to 'The effectiveness of integrated farm management, organic farming and agrienvironment schemes for conserving biodiversity in temperate Europe (defined here as European countries west of Russia, but not those south of France, Switzerland, Austria, Hungary and Romania) with an emphasis on birds and invertebrates. The resulting database can be used to identify knowledge gaps to inform future primary research, other research synthesis methods such as synopses of evidence, and synthesis and evaluation methods such as systematic review.

\section{Systematic maps and their use in social sciences}

Systematic mapping is used in social sciences to provide an overview of evidence for broad research questions. Systematic mapping like systematic review, is a robust, repeatable and transparent scientific method used to identify and categorise available literature on a particular topic. It uses established searching protocols and has rigorous criteria for inclusion or exclusion.

Unlike systematic review, however, systematic maps are not used to attempt to answer a question, and do not usually attempt full data extraction or critical appraisal of the relevant research. Instead, they identify and describe the nature, volume and characteristics of research in a chosen field $[25,26]$.

Systematic maps can be used to review broad topic areas [27] and categorise the literature according to topic area, study design, and other factors of relevance to the reviewers [26]. 
The information from systematic maps can be used as a tool for decision makers or to identify where studies are similar enough for robust syntheses such as systematic review [26]. Systematic maps can also identify knowledge gaps to inform primary research [27,28]. This differs from scoping reviews, which are usually preliminary assessments of the size and scope of literature in a topic area, and are not usually considered final outputs in their own right [26].

\section{Systematic mapping as a tool for environmental scientists} To date, the adaptation of systematic mapping methodology for environmental evidence is in the early stages and there is no formal methodology for applying it to environmental sciences.

We adapted methodology for systematic mapping from the Social Care Institute for Excellence [27]. Figure 1 provides an overview of the process. A searchable database is created to show the available research on a topic, and this together with an associated summary report forms the systematic map.

\section{Objective of the map \\ Objective formulation}

The question of how different farming systems compare in their effects on biodiversity and other environmental impacts was recently identified by policy makers and scientists as one of the top 100 policy-relevant ecological questions in the UK: 'How do farming systems such as conventional, integrate farm management and organic compare in terms of their effects on biodiversity and other environmental impacts?' The need to learn from Agri-environment Schemes to optimise future biodiversity gain and ecological benefits was also prioritised [29].

The need for a systematic review to answer these questions was discussed by a stakeholder group comprising; the UK Department for Environment Food and Rural Affairs (Defra), Natural England, Countryside Council for Wales, Farming and Wildlife Advisory Group, Linking Environment and Farming (LEAF) and individual farmer representatives. Feedback from meetings was incorporated into the finalised protocol to shape the review question and search strategy.

Stakeholders agreed that the study should focus on 'temperate' Europe, rather than solely on the UK, because these countries have similar farming systems, and a significant amount of money is invested into agrienvironment schemes throughout the European Union $[13,30]$. The questions of how best to produce food sustainably, including the protection, maintenance and enhancement of farmland biodiversity are included in the European Commissions recent consultation into the Common Agricultural Policy [2], confirming the need to

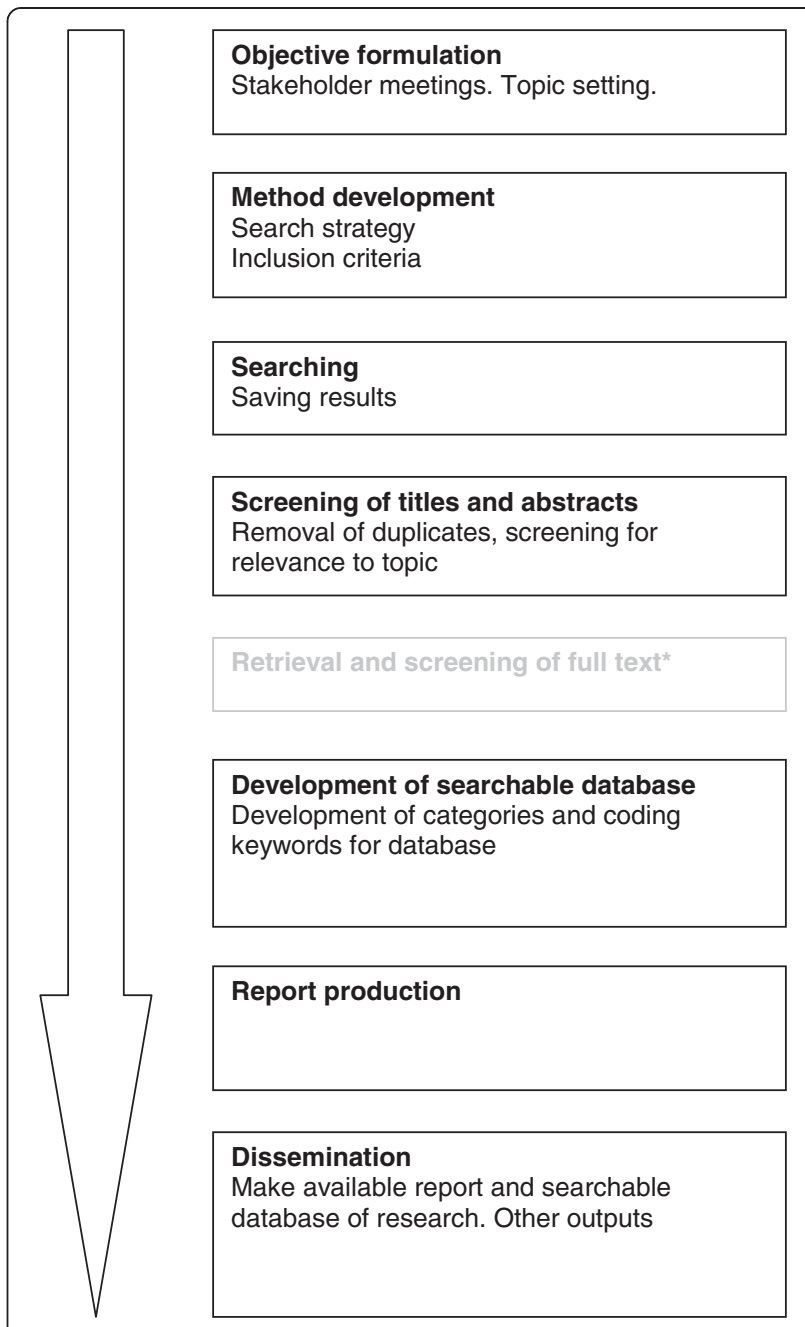

Figure 1 Stages of mapping (adapted from Clapton, Rutter and Sharif, 2009 [27]). *For this article full text articles were not retrieved or screened.

understand the benefits to biodiversity to ensure value for money, and to further improve the schemes.

A systematic review search strategy was established in 2008. A particular emphasis was placed on birds and invertebrates at the request of stakeholders, but the searches captured a large volume of relevant but disparate literature. When, in 2010, funding and resources became available to further the research, it became evident that the topic area was too broad for systematic review synthesis and alternative methods of presenting the data were considered. Subsequently the question posed by the group was formulated into a primary objective for a systematic map instead of a systematic review.

\section{Primary objective}

The study aimed to identify and systematically map published and unpublished research to address the following primary objective: 
- To describe and map research that investigates the effectiveness of integrated farm management, organic farming and agri-environment schemes as interventions for conserving biodiversity in temperate Europe.

\section{Secondary objectives}

The secondary objectives were to:

- Describe how the research into these farm-scale interventions on biodiversity varies between different regions, farming-systems, agri-environmental options/ farmland biotopes and types of organism.

- Provide an overview of published research and grey literature in the subject area for use by practitioners, policymakers, researchers and the public.

- Provide a map that is searchable by topic

- Inform future research synthesis and evaluation methods such as systematic review and synopses of evidence

- Identify knowledge gaps in order to inform future primary research

\section{Methods}

The methods used in the development of the systematic map were adapted from Collaboration for Environmental Evidence (CEE) Systematic Review Guidelines [31], from existing systematic map reports [32,33] and Social Care Institute for Excellence (SCIE) Guidelines [25,27].

\section{Searches}

A comprehensive search of several information sources attempted to achieve an un-biased sample of both published and grey literature. There were two search phases, the first in 2008 and the second search in 2010, where the search was updated, and new databases were searched.

The following online literature databases were searched to identify relevant literature:

1) ISI Web of Knowledge involving the following products: ISI Web of Science; ISI Proceedings

2) Science Direct

3) Blackwell Synergy

4) Ingenta Connect

5) Index to Theses Online

6) $\mathrm{CAB}$ Abstracts

7) Centre for Ecology and Hydrology online database

8) Conservation Evidence.com

9) UK Department for Environment food and Rural Affairs online

\section{0) NERC Open Research Archive}

In addition, web searches were performed using the search engines: WWW.ALLTHEWEB.COM and HTTP:// SCHOLAR.GOOGLE.COM. The first 50 hits (.doc .txt . xls and .pdf documents where this can be separated) from each data source were examined for appropriate data. No further links from the captured website were followed unless to a document/pdf file.

Database and repository searches were conducted in English language. A wildcard (*) was used to pick up multiple word endings (eg. Farm* would pick up farms, farming etc.). Birds and invertebrates were specifically searched for as potential farmland biodiversity indicators at the request of the original stakeholder group. The following terms were used in combination to search the online databases/web searches:

Farm* AND biodiversity

Organic AND biodiversity

Farm* AND (diversity or abundance) not fish

Agri-environment"

(Farmland or farming) AND bird*

(Farm* AND invertebrate*) not fish

Agri-environment" AND biodiversity

Where wildcards were not permitted extra searches were carried out to cover multiple word endings. 'Integrated farm management' was not searched for as a phrase, as any searches with farm* would have identified these references. Brackets were only used where databases allowed.

The results of the searches were imported into EndNote $\mathrm{X} 2^{\mathrm{TM}}$ library files. A separate file was made for each search made. When searching was complete, all the database libraries were incorporated into one new library, and the number of references captured was recorded. Using the automatic function in the EndNote $\mathrm{X} 2^{\mathrm{TM}}$ software, any duplicates were removed. The library was then searched for references relevant to the topic.

\section{Study inclusion criteria}

The inclusion criteria were applied by one reviewer to all studies at title and abstract level. For a random 20\% of studies, and where it was not clear whether a study met the inclusion criteria, the study was screened by a second reviewer and any differences resolved through discussion. Reviewers discussed the procedures to ensure a consistent understanding of the criteria at both the screening and coding stages.

Relevant subject(s): Studies on some aspect of biodiversity or species diversity on farmland were included, irrespective of scale. All biotopes were included except 
for ponds, farm woodland and orchards. The scope of temperate Europe was defined as all European countries west of Russia, but not those south of France, Switzerland Austria, Hungary and Romania.

Types of intervention: Interventions that aimed to increase biodiversity on farmland, or some element of it, were considered: these included organic farming and integrated farm management, named agrienvironment schemes, and specific options and biotopes that could form part of agri-environment, organic or integrated farming schemes.

Types of comparator: Conventional farming or a conventionally farmed plot.

Types of outcome: Effects on any organism or organisms excluding fungi, bacteria and agricultural pests. Any measure of biodiversity was considered. Differences or similarities in biodiversity on different farm types, and differences or similarities in biodiversity following management changes on farmland were considered.

Types of study: Any type of study that investigated biodiversity on farmland was considered, including correlative studies and manipulative studies but not pure ecology studies, statistical models, or review papers. Systematic maps, lacking strict critical appraisal, often include studies that would not be included in systematic reviews [27]. Only primary research studies were incorporated into the final systematic map.

Language: Studies published in English.

Date: No date restrictions were applied, but searches were limited according to the scope of the individual databases.

There was a high volume of irrelevant references present in the intial library (for example large numbers of medical papers referring to biodiversity of the gut were present) so some filters were made of keywords in the title to aid exclusion of irrelevant references. The titles of all records filtered by this method were visually checked to ensure that no potentially relevant references were excluded. Where there was doubt about relevance, records were removed from the exclusion list and passed to the next inclusion stage. The references were then hand searched for relevance, first by title, and then by title and abstract. Due to the high volume of relevant literature captured, searching was taken to the abstract phase only, full text was not retrieved. The resulting references were used to formulate a database.

\section{Definitions}

Definitions are important when both searching and screening [33]. When creating the searchable database clear definitions help to overcome ambiguity and improve rigour. The operational definitions and clarification of the categories used for the systematic map are detailed in an additional file (Additional File 1).

\section{Recording the search and screening}

A record of each search was made to enable a re-run of the search if needed.

The following data were recorded: date of search, database name, search term, number of hits, date limits of the database searched (e.g. 1999-2006), and notes. For each stage of the screening process the number of references obtained and excluded was recorded.

\section{Coding for the systematic map}

Key wording was used to describe, categorise and code studies. Systematic map reports can present data by country of origin, publication date, intervention type etc. Coding should be determined on a review-by-review basis [27].

Keywords were generated from the primary question, expert knowledge in the subject area and topics reported in the studies.

A wide range of organisms were studied in the publications. Individual species were not recorded as this would have further expanded and complicated the database. Instead organisms were categorised as general groups: invertebrate, plant, bird, mammal, reptile or amphibian. Invertebrates were further categorised into four functional groups (identified as important for farmland systems by the stakeholder workshop participants): pollinators, natural enemies, soil organisms and invertebrate food for farmland birds. Some functional groups were further divided. For example, pollinators have been subdivided into Lepidoptera (butterflies), Bombus spp. (bumblebees), Apoidae (solitary bees and unspecified bees) and Syrphidae (hoverflies). A subcategory 'plants of conservation concern' was also made where study authors had identified that the plants included in the research were of particular local or national conservation interest and/or that receive funding through agrienvironment schemes.

The articles were coded under the following categories: author, full reference, date of publication, publication type, length of time of study, country/ies of study, spatial scale of experiment, farming system, farming prescription/intervention, biotope, organism, outcome investigated, and experimental design. Studies were defined as either correlative (where biodiversity outcomes had been compared between different biotopes as found) or manipulative (where artificial treatments were applied to test for effects on biodiversity). Studies could appear under more than one category where relevant. For example butterflies were categorised as invertebrate, pollinator, and as butterfly. 
The coding was carefully moderated. All included articles were coded by one reviewer, and scrutinised by a second reviewer. Coding keywords were revised to resolve any inconsistencies between reviewers or in response to search findings. Any articles already coded, were re-coded using the revised keywords. A sample of coded articles was cross checked by a third independent reviewer to confirm understanding of coding.

The included references were exported from the EndNoteX2 ${ }^{\mathrm{TM}}$ library to a Microsoft excel workbook where the coding was applied. Details of the keyword coding used for each category included in the systematic map database are given in an additional file (Additional File 2).

\section{Systematic map database}

A searchable map (database) was created to describe the scope of the research and identify apparent knowledge gaps. It can be used for further analysis as it enables both simple numerical accounts of the frequencies in each category, and more complex cross tablulations. The searchable database is included as a Microsoft Access file (Additional File 3) and details of how to search the database are provided separately (Additional File 4).

The systematic map data can be ordered by topic area, publication date, intervention type, organism, country of study etc. Cross tabulations can be generated from the map to allow reviewers to find correlations and trends and identify areas where there are no research outputs available. For example, interactions between farming system and agri-environment scheme can be displayed or used to examine whether there is bias towards an individual agri-environment scheme and its effect on a particular organism.

\section{Results}

\section{Review descriptive statistics}

The searches identified 83,590 records. Of these, 31,371 were found in the 2008 searches, and 52,219 by the 2010 searches. The 2010 searches were a combination of updates to the 2008 searches, and completes searches of some databases hence the higher number of hits in 2010. The number of records generated for specific searches are detailed in an additional file (Additional file $5)$. The records were screened for inclusion in the systematic map as illustrated in Figure 2.

A total of 743 articles were judged to have met the inclusion criteria based on title and abstract, and included in the final systematic map. The list of articles is provided in an additional file (Additional file 6). Each article was coded for the database. An online version of the systematic map is available as an electronic database, searchable by keyword, and can be found as an additional file (Additional file 3). Six articles were found that were either meta-analyses or systematic reviews. These were not included in the systematic map database, but have been included as an additional file (Additional File 7).

Of the 743 records included in the map, 388 articles reported on correlative studies and 339 manipulative. Sixteen records contained a combination of correlative and manipulative studies presented in the same article. These were predominantly $\mathrm{PhD}$ theses.

Overall, the majority of articles were journal papers (73\%, $n=539)$, followed by conference papers (16\%, $n=121)$ and theses $(6 \%, n=47)$. The remaining articles (5\%) were reported within books or were organisation reports and final reports for the UK Department for Environment Food and Rural Affairs. Where information from one study (although not necessarily the same data) was presented in one or more articles, for example a thesis, conference paper and refereed journal, they were classified as 'multiple outputs of one study' (total =116). All outputs found on any study were included within the database. Any known multiple outputs were marked as such.

The earliest article recorded was in 1962, and there was a substantial increase in the number of articles found year by year up to the present day (Figure 3).

\section{Country of origin}

Whilst the country of origin was not mentioned in many abstracts $(n=181)$ most studies were carried out in the UK $(n=280)$. Most of the remaining studies originated from Western European countries (particularly Germany, Switzerland, the Netherlands) when compared with the Eastern European countries included in this study (eg. Czech Republic, Slovakia, Latvia) (Figure 4). No studies were found for Romania, the Ukraine, Moldovia, or Belaruse.

\section{Scale}

Most studies were performed across a variety of spatial scales. The most common combination was 'within-field' 'multiple farm'. I.e. the study compared specific withinfield interventions (such as field margin) with other interventions or crops, and evaluated results across a number of farms. Many of these studies could also be considered 'landscape scale' as studies were conducted on multiple farms in different regions of the UK. Very few articles $(n=12)$ reported studies made at the 'whole farm scale', i.e. investigating the impact of a named intervention (such as agri-environment scheme implementation) on biodiversity across the whole farm. A breakdown of the spatial scales of studies is given in Table 1 . Some abstracts $(n=24)$ did not mention a spatial scale at all, and in other cases it was possible to discern some aspects of spatial scale, but not others (for example, experiments may have been described as 
'within field', but no mention given of whether this was replicated within one or multiple farms).

\section{Period of study}

Most abstracts $(n=396)$ did not mention the period of time over which the work took place. Of the remaining, most studies (50\%) were between 1 and 3 years duration, $19 \%$ were less than a year in duration, $10 \%$ took place over 4 years, $12 \%$ were carried out over 5 to 9 years, and $9 \%$ were carried out over 10 years or more.

\section{Organisms and functional groups}

Invertebrates were the most commonly studied organisms $(n=422)$. Followed by plants $(n=243)$ and birds $(n=226)$. There were very few studies on mammals and less on reptiles or amphibians (Figure 5). As specific searches were made for invertebrates and for birds, but not for other types of organisms, this is likely to have resulted in bias. Freshwater biotopes were not included in the searches and were screened out, which is likely to have had an impact on organisms specifically associated with them. 


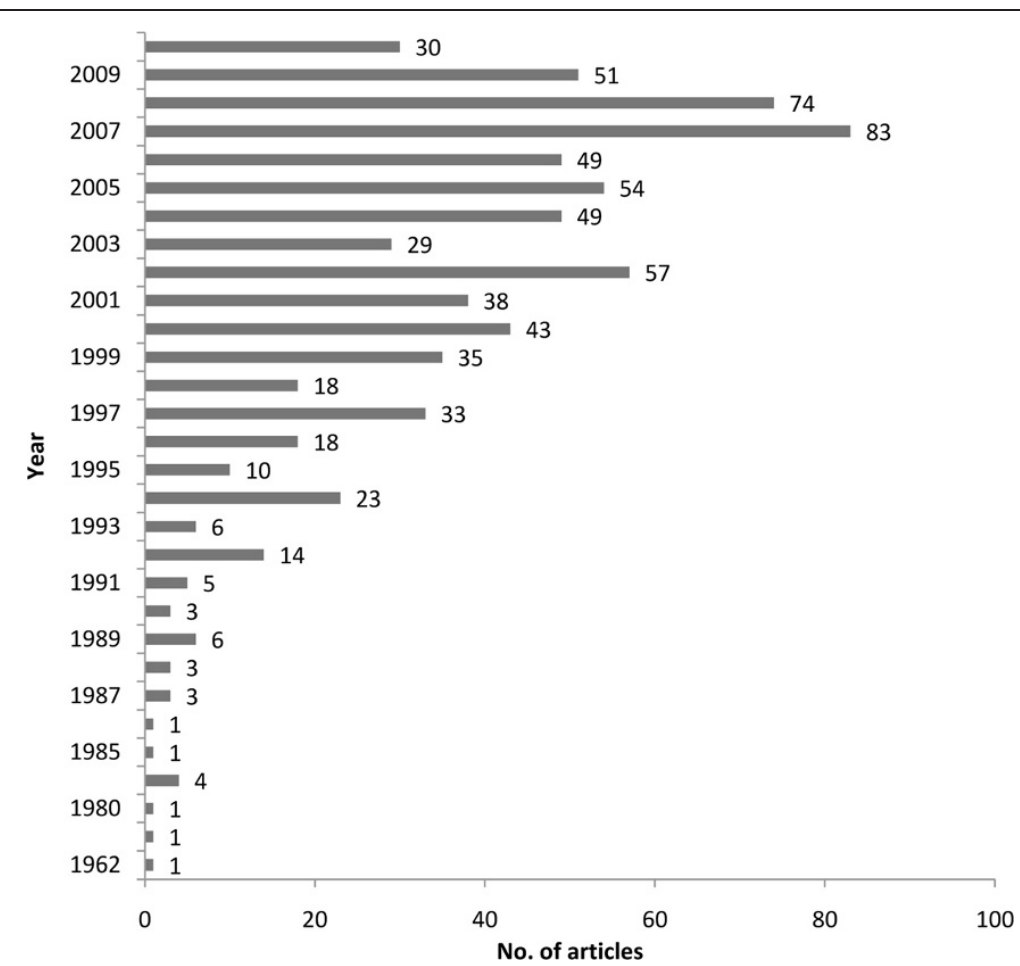

Figure 3 Number of articles by year. The apparent increase will reflect (at least in part) bias in dates available for the databases searched.

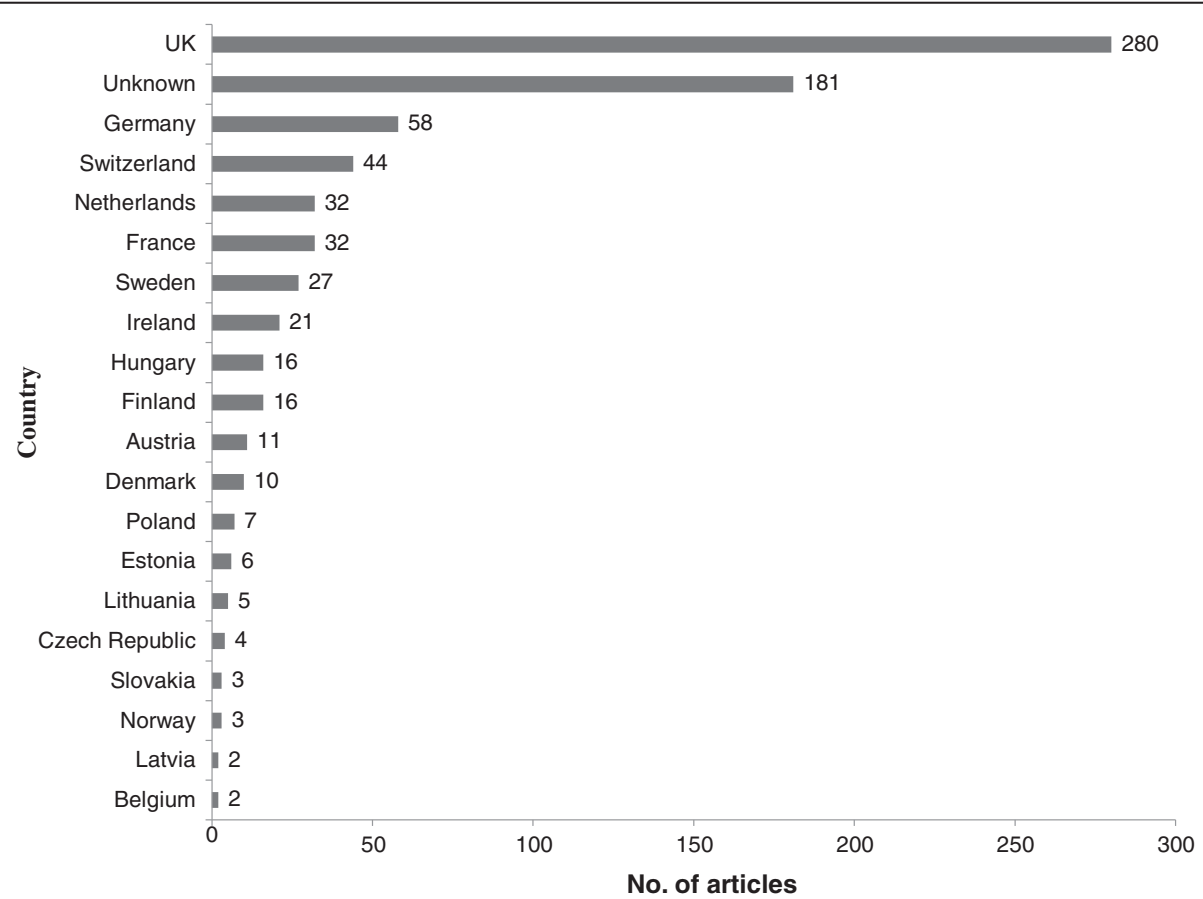

Figure 4 Country of Origin of study. The total number of publications is shown at the end of each column. The overall total is more than 743 because some studies were performed in more than one country. The bias towards UK studies is likely to reflect (at least in part) the English language searching and coding strategy used. 
Table 1 The number of articles at each spatial scale recorded

\begin{tabular}{ll}
\hline Scale & No. of articles \\
\hline Landscape & 206 \\
Multiple farm & 350 \\
Single farm & 98 \\
Whole farm & 12 \\
Within field & 680 \\
\hline
\end{tabular}

The total number of articles exceeds 743 because some studies were performed on multiple farms at landscape scale, within field. Some abstracts did not include details of spatial scale so are not included in the totals.

Correlative and manipulative studies were found in similar numbers of articles for most groups, with the exception of birds, which were most commonly investigated in correlative studies (145 correlative; 75 manipulative; 6 combined correlative and manipulative). Articles reporting plants studies were slightly biased towards manipulative research (135 manipulative; 103 correlative; 5 combined correlative and manipulative) (Figure 5).

Four functional groups were selected to be investigated further to investigate the scope of evidence relating to these subgroups. This also provided an indication of the breakdown of the invertebrate composition, the most commonly studied taxanomic group. Pollinators $(n=128)$ and natural enemies $(n=127)$ were the most studied functional groups. There were fewer study articles for soil organisms $(n=58)$ and invertebrate food for farmland birds $(n=46)$. There were similar numbers of correlative and manipulative studies for each functional group. Pollinator studies were mainly on Lepidoptera (butterflies) (52\% of articles) and Bombus sp. (bumblebees) (34\%). Studies on Apoidae (unspecified bees) (21\%), Syrphidae (hoverflies) (16\%), Apis sp. (honey bees) (5\%) and Apoidae (solitary bees) (5\%) made up the remainder. Natural enemy studies were mainly of Araneae (spiders) (71\% of articles) and Carabidae (ground beetles) (48\%) and to a lesser extent on Staphylinidae (rove beetles) (22\%) and Syrphidae (hoverflies) (7\%). Lumbricadae (earthworms) were the most commonly studied soil inverebrate $(n=35)$ followed by Collembola (springtails) $(n=14)$. The remaining 9 articles either investigated other soil invertebrates or the organism was not mentioned in the abstract.

Only 17 articles reported investigations of plants which were of particular conservation interest either in the country or locality of the study due to rarity or declines. These were categorised separately within the database as 'plants of conservation concern' as some receive conservation funding through the Common Agricultural Policy.

Out of the 743 articles, 698 abstracts reported the outcome measured, most commonly abundance. This was followed by diversity, richness, density, composition, reproductive success, survival and distribution. Figure 6 shows the number of times each outcome was recorded.

\section{Farming system and biodiversity}

Studies investigating farming system and biodiversity encompassed a wide variety of subject area, scales and design. For example, multiple farm studies sometimes compared biodiversity between matched pairs of different farming systems (such as organic and non-organic) [34], whereas others investigated changes in biodiversity on farms during conversion from conventional to organic or integrated farming systems [19,35 for example]. Other studies looked at the impact on biodiversity of management of biotopes such as field margins [36] or farm practices such as fertilisation [37] in specific farming systems.

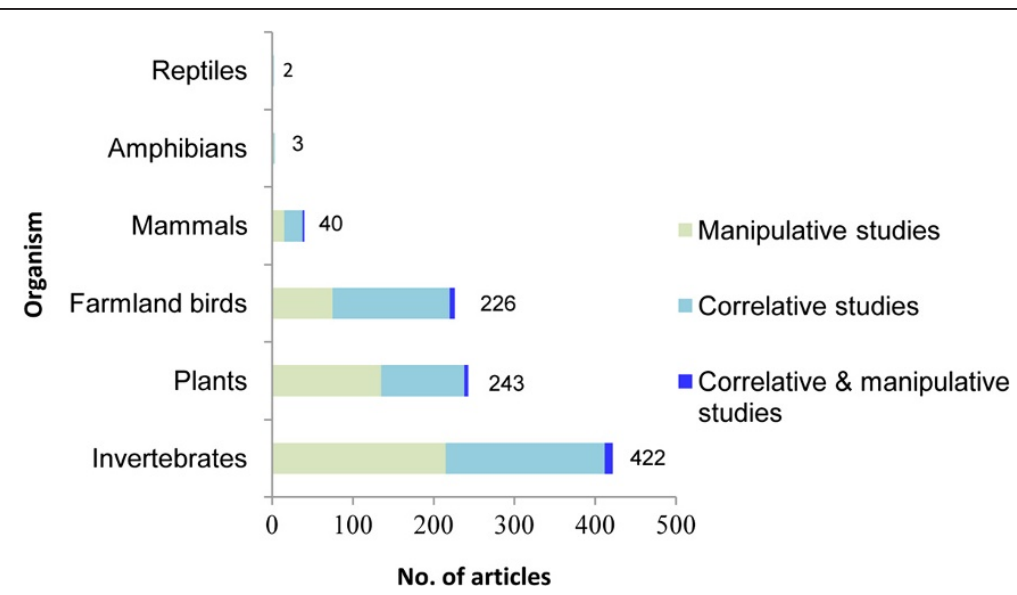

Figure 5 Number of articles for each type of organism. Total number of articles for each is presented at the end of each column. The total number of articles exceeds 743 because more than one organism may have been investigated in a study. 


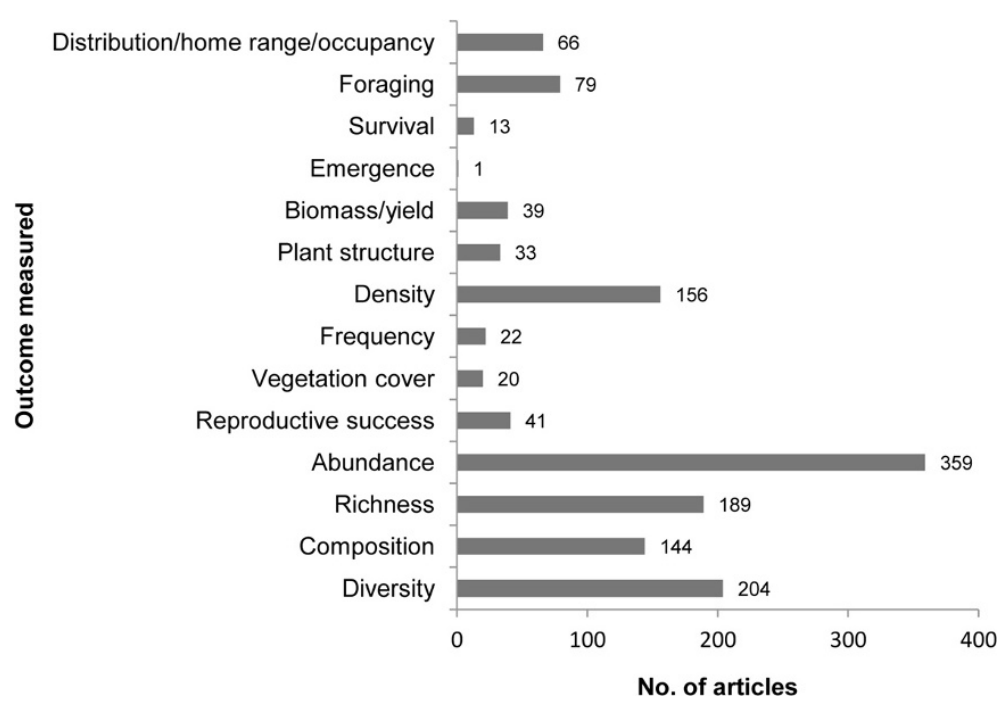

Figure 6 Number of times each outcome is reported.

\section{Organic \& integrated farming systems}

The number of studies of organic farming increased from the late 1990s. In contrast, those of integrated farming stayed at a low level throughout, although numbers did increase slightly in the 1990s before declining again (Figure 7).

Most studies of organic farming were in Western Europe, especially the UK and Germany (UK $n=31$ articles; Germany $n=22$; Sweden, Netherlands and Switzerland $n=8$ each; Denmark $n=7$; Austria $n=6$; France $n=4$; Ireland and Finland $n=1)$. Studies from Eastern Europe were from Estonia $(n=3)$, Slovakia $(n=2)$, Poland, Hungary \& Czech Republic ( $n=1$ each).
The incidence was similar for integrated farm management with 36 articles reporting studies from Western Europe (UK $n=20$; Germany $n=9$; Switzerland $n=6$; Finland and Netherlands $n=1$ ) and 3 Eastern European countries (Estonia, Lithuania and Slovakia $n=1$ each).

More correlative studies were found for organic farming than for integrated farming but the number of manipulative studies was similar. Most comparisons of organic and conventional farming were correlative, whereas those of integrated and conventional farming were manipulative. Eight articles reported studies comparing organic and integrated farming systems (Table 2).

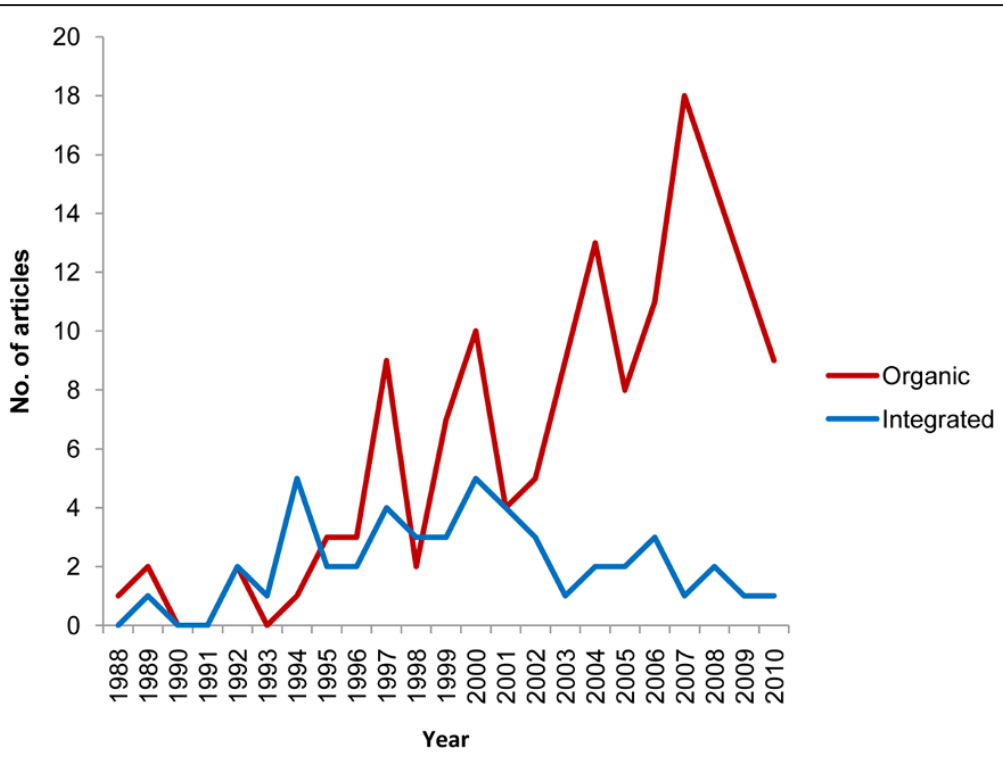

Figure 7 Number of articles for of organic and integrated farming by year. 
Table 2 The number of articles reporting correlative and manipulative studies of organic, conventional and integrated farming systems

\begin{tabular}{|c|c|c|c|c|}
\hline & Correlative & Manipulative & $\begin{array}{l}\text { Correlative and } \\
\text { manipulative }\end{array}$ & Total \\
\hline Organic & 117 & 27 & 2 & 144 \\
\hline Conventional & 112 & 39 & 2 & 151 \\
\hline Integrated & 20 & 28 & 0 & 48 \\
\hline Organic versus conventional farm management & 89 & 14 & 2 & 103 \\
\hline Organic versus conventional versus integrated farm management & 11 & 4 & 0 & 15 \\
\hline Integrated versus conventional farm management & 3 & 17 & 0 & 20 \\
\hline Organic versus integrated farm management & 6 & 2 & 0 & 8 \\
\hline
\end{tabular}

Table 3 summarises the number of articles for organism and functional group in organic, conventional and integrated farming systems. Invertebrates were the most studied group for all systems followed by plants and birds. Few studies examined mammals and plants of conservation concern and no studies were found for amphibians or reptiles. Invertebrates are considered important to organic and integrated farming, particularly natural enemies which are often used as a form of pest control. It was therefore unsurprising to find that natural enemies were the most studied invertebrate functional group. Soil organisms are also important in these systems for maintaining healthy soils and this is reflected in the number of articles captured. Natural enemies $(n=8)$ and soil organisms $(n=7)$ were also the most studied functional groups in comparisons of integrated and conventional farm management. In contrast, when organic and converntional farming systems were compared, plants $(n=36)$ and birds $(n=24)$ were more commonly reported than any invertebrate functional group. Pollinator studies were reported far more frequently in comparisons between organic and conventional farming systems $(n=13)$ than in integrated farming systems $(n=2)$. There were very few studies of farming system and invertebrate food for farmland birds.

\section{Other farming systems studied}

Other farming systems, captured and included in the map included conservation tillage (Table 4) and extensive grassland management, in particular "extensive" grazing systems. These can be used as agri-environment options, or be a component of specific farming systems. For example, noninversion tillage is practiced in integrated farm management [38].

Invertebrates, particularly soil organisms, were the focus of the tillage studies. One of the aims of conservation tillage is to reduce soil organism mortality, and so improve soil condition. Conservation tillage can also indirectly benefit other organisms by increasing prey availability (invertebrate food for birds for example).

Invertebrates, particularly pollinators, were also the most commonly reported study organisms in experiments investigating grassland (Table 5) and grazing (Table 6) systems. The number of studies investigating plants and birds in the two systems was similar. Few studies investigated mammals and none were found for amphibians or reptiles.

\section{Impact of agri-environment scheme}

The abstracts of 64 articles stated that they were comparing farms under agri-environment schemes with those not under them. The actual prescriptions may or may not have been mentioned. These were predominantly manipulative studies (86\%). There were only 3 articles for Eastern Europe (Czech Republic $\mathrm{n}=1$ and Estonia $\mathrm{n}=2)$. The others were: UK $(n=29)$; Switzerland $(n=13) ;$ Netherlands $(n=8)$; Ireland $(n=6)$; Austria $(n=2)$; France and Germany $(n=1$ each $)$. Two articles did not give a country in the abstract, although from personal knowledge, one was UK. Invertebrates $(n=33)$, plants $(n=31)$ and farmland birds $(n=26)$ were the most commonly studied groups. Few studies investigated mammals and none amphibians or reptiles (Figure 8). Pollinators were the most common functional group, with half on butterflies $(n=10)$ and the others on unspecified bees $(n=7)$, bumblebees $(n=3)$ and hoverflies $(n=2)$. Figure 9 shows the number of articles for specific management options. Field margins $(n=17)$, Meadows $(n=10)$ including Ecological Compensation Area Meadows (specific to Switzerland $n=9$ ) and hedgerows $(n=11)$ were the most common. It may be that more evidence is needed to test the efficacy of management options. Some options are for specific organisms eg. Lapwing option, whereas others are not. Table 7 gives the group studied for each option.

\section{Biotope/agri-environment options}

Twenty six types of biotope intervention were identified, and recorded in the database. Arable crop and grass field, however, were usually used either as a comparator (in [39] for example, bumblebee numbers on experimental field margins were compared to those of the arable crop), or associated with other interventions such as 
Table 3 Number of articles for farming system and type of organism

\begin{tabular}{|c|c|c|c|c|c|c|c|c|c|}
\hline & Invertebrates & Plants & $\begin{array}{l}\text { Farmland } \\
\text { birds }\end{array}$ & Mammals & $\begin{array}{l}\text { Plants of } \\
\text { conservation } \\
\text { concern }\end{array}$ & Pollinators & $\begin{array}{l}\text { Natural } \\
\text { enemies }\end{array}$ & $\begin{array}{l}\text { Soil } \\
\text { organisms }\end{array}$ & $\begin{array}{l}\text { Invertebrate } \\
\text { food for } \\
\text { farmland birds }\end{array}$ \\
\hline Organic & 88 & 50 & 28 & 7 & 6 & 18 & 30 & 17 & 3 \\
\hline Conventional & 95 & 46 & 30 & 8 & 4 & 16 & 32 & 21 & 6 \\
\hline Integrated & 35 & 7 & 8 & 2 & 1 & 2 & 17 & 13 & 1 \\
\hline $\begin{array}{l}\text { Organic versus conventional } \\
\text { farm management }\end{array}$ & 58 & 36 & 24 & 6 & 3 & 13 & 19 & 10 & 3 \\
\hline $\begin{array}{l}\text { Organic versus conventional versus } \\
\text { integrated farmmanagement }\end{array}$ & 9 & 4 & 1 & 1 & 0 & 1 & 4 & 3 & 0 \\
\hline $\begin{array}{l}\text { Integrated versus } \\
\text { conventional farm management }\end{array}$ & 18 & 0 & 3 & 0 & 0 & 1 & 8 & 7 & 1 \\
\hline $\begin{array}{l}\text { Organic versus integrated } \\
\text { farm management }\end{array}$ & 6 & 2 & 1 & 0 & 1 & 0 & 4 & 1 & 0 \\
\hline
\end{tabular}


Table 4 Number articles for tillage

\begin{tabular}{|c|c|c|c|c|c|c|c|}
\hline & Invertebrates & $\begin{array}{l}\text { Natural } \\
\text { enemies }\end{array}$ & $\begin{array}{l}\text { Soil } \\
\text { organisms }\end{array}$ & Plants & $\begin{array}{l}\text { Farmland } \\
\text { birds }\end{array}$ & Mammals & $\begin{array}{l}\text { Plants of } \\
\text { cons concern }\end{array}$ \\
\hline $\begin{array}{l}\text { Total tillage } \\
\text { publications }\end{array}$ & 26 & 7 & 19 & 6 & 10 & 1 & 2 \\
\hline Ploughing & 23 & 7 & 17 & 4 & 7 & 0 & 1 \\
\hline $\begin{array}{l}\text { Non inversion } \\
\text { tillage }\end{array}$ & 12 & 5 & 8 & 3 & 6 & 0 & 0 \\
\hline $\begin{array}{l}\text { Minimal } \\
\text { tillage }\end{array}$ & 17 & 2 & 14 & 2 & 3 & 1 & 2 \\
\hline
\end{tabular}

More than one organism/functional group may have been investigated in a study. The number of articles for each taxanomic group will reflect (at least in part) the search terms used.

farming system, (for example in comparisons of collembola numbers in conventional, organic or integrated farm management winter wheat [40]).

Field margins were the most commonly studied of the remaining biotopes ( $n=215$ articles). Studies on field margins, hedgerows, set-aside, meadows and semi-natural grassland were particularly varied, from investigating them under different farming systems and testing different management or restoration options to comparing their use with other biotopes by a number of different organisms.

Studies of interventions that were specifically designed as agri-environmental options were generally manipulative. Examples of this included, wild bird cover, conservation headlands, skylark plots, beetle banks and the Lapwing option. These type of options tend to be simple to implement on small scales, and are often targeted towards particular organisms so may be more conducive to manipulative studies. However, some named agrienvironmental scheme options were more studied than others and, where named, often tended to be UK schemes. For example, conservation headlands ( $n=24$ articles), wild bird cover $(n=23)$ and beetle banks $(n=16)$ are all UK current or historic agri-environment schemes.

Many studies on hedgerows were correlative as were all those on green lanes. The numbers of correlative and manipulative studies were similar for semi-natural grassland, set-aside, field margins, lowland wet grassland, meadows, ditches and overwintered stubbles. The numbers of articles reporting the effect of specific biotope or agrienvironment interventions are detailed in Figure 10.
Table 8 shows cross-tablulations of the number of articles found for biotope intervention and organism type. As above, most research investigated invertebrates, plants and farmland birds. Publications on mammals were much less common, being mainly studied in field margins, hedgerows and set-aside. No studies were found for amphibians and reptiles.

The subject organism often reflects the intent of the intervention. For example, wild bird cover tries to provide winter seed for farmland birds and most studies (17 of 24) were on birds but some investigated affects on other organisms either in addition or instead. Some options designed for birds (e.g. overwinter stubbles and skylark plots) often examine plants and invertebrates as these provide food sources for birds. Field margins on the other hand provide a habitat for a wide range of organisms but there has been a disproportionate amount of research on invertebrates.

Plants of conservation concern are often found within arable crops and grass fields. Five articles were found for plants of conservation concern in arable crops, and 2 for grass field.

\section{Studies of the effect of farming system on the biodiversity of biotope}

As before, fallow studies were included within set-aside, riparian buffer strips in field margins and Ecological Compensation Area meadows in meadow management. In the database these are listed separately.

Table 5 Number of articles for grassland system

\begin{tabular}{|c|c|c|c|c|c|c|c|c|}
\hline & Invertebrates & Plants & $\begin{array}{l}\text { Farmland } \\
\text { birds }\end{array}$ & $\begin{array}{l}\text { Plants of } \\
\text { cons } \\
\text { concern }\end{array}$ & Pollinators & $\begin{array}{l}\text { Natural } \\
\text { enemies }\end{array}$ & $\begin{array}{l}\text { Soil } \\
\text { organisms }\end{array}$ & $\begin{array}{l}\text { Invert food for } \\
\text { farmland birds }\end{array}$ \\
\hline Intensive grassland & 28 & 18 & 12 & 0 & 5 & 6 & 3 & 7 \\
\hline Extensive grassland & 22 & 13 & 8 & 1 & 5 & 6 & 3 & 6 \\
\hline $\begin{array}{l}\text { Intensiveversus extensive } \\
\text { grassland }\end{array}$ & 19 & 7 & 7 & 0 & 4 & 5 & 3 & 6 \\
\hline
\end{tabular}

More than one organism/functional group may have been investigated in a study. Where an article is categorised as 'intensive versus extensive grassland', it will also be included within the 'intensive grassland' and 'extensive grassland' categories. The number of articles for each taxanomic group will reflect (at least in part) the search terms used. 
Table 6 Number of articles for grazing

\begin{tabular}{|c|c|c|c|c|c|c|c|c|c|}
\hline & Invertebrates & Plants & $\begin{array}{l}\text { Farmland } \\
\text { birds }\end{array}$ & Mammals & $\begin{array}{l}\text { Plants of } \\
\text { cons } \\
\text { concern }\end{array}$ & Pollinators & $\begin{array}{l}\text { Natural } \\
\text { enemies }\end{array}$ & $\begin{array}{l}\text { Soil } \\
\text { organisms }\end{array}$ & $\begin{array}{l}\text { Invert food } \\
\text { for farmland } \\
\text { birds }\end{array}$ \\
\hline $\begin{array}{l}\text { Grazing intensity } \\
\text { unspecified }\end{array}$ & 17 & 13 & 10 & 2 & 2 & 7 & 3 & 1 & 1 \\
\hline Intensively grazed & 14 & 5 & 5 & 1 & 0 & 2 & 5 & 1 & 3 \\
\hline Extensively grazed & 15 & 6 & 8 & 2 & 0 & 4 & 4 & 1 & 3 \\
\hline $\begin{array}{l}\text { Intensive versus } \\
\text { extensively grazed }\end{array}$ & 13 & 4 & 5 & 1 & 0 & 2 & 4 & 1 & 3 \\
\hline
\end{tabular}

More than one organism/functional group may have been investigated in a study. Where an article is categorised as 'intensive versus extensively grazed', it will also be included within the 'intensively grazed' and 'extensively grazed' categories. The number of articles for each taxanomic group will reflect (at least in part) the search terms used.

Few studies investigated the effect of different farming systems on the biodiversity of biotope. Of the 23 biotopes/ interventions listed in Table 8 only eight have been investigated for farming system. These are shown in Table 9.

Most studies were on the biodiversity of field margins in either organic or conventional farming systems, or systems that compared the two. The number of articles for each type of organism on field margins in different farming systems is shown in Table 10. The majority of these were correlative and investigated invertebrates. Pollinators, in particular butterflies, predominated in comparisons between conventional and organic systems. There were few studies of field margins on integrated farms.

There were about half as many studies of hedgerows as of field margins but their distribution between farming system and group of organism was similar. The number of articles for each type of organism for hedgerows in different farming systems is shown in Table 11. There were few studies of the remaining habitats.

\section{Discussion}

\section{General trends}

- The amount of literature found each year generally increased up to the present day. This is likely to reflect changes in policy on the farmed environment in temperate Europe, but could also be affected by known bias in the searches.

- Most studies were from Western Europe, in particular the UK where there has been a long history of such research. This will also reflect bias in the search strategy.

- The literature found was predominantly published in peer reviewed journals.

- Invertebrates were the most frequently studied type of organism, possibly because invertebrates are easily observed, provide food resource for other organisms, and may form important functional groups in agriculture (e.g., natural enemies and pollinators).

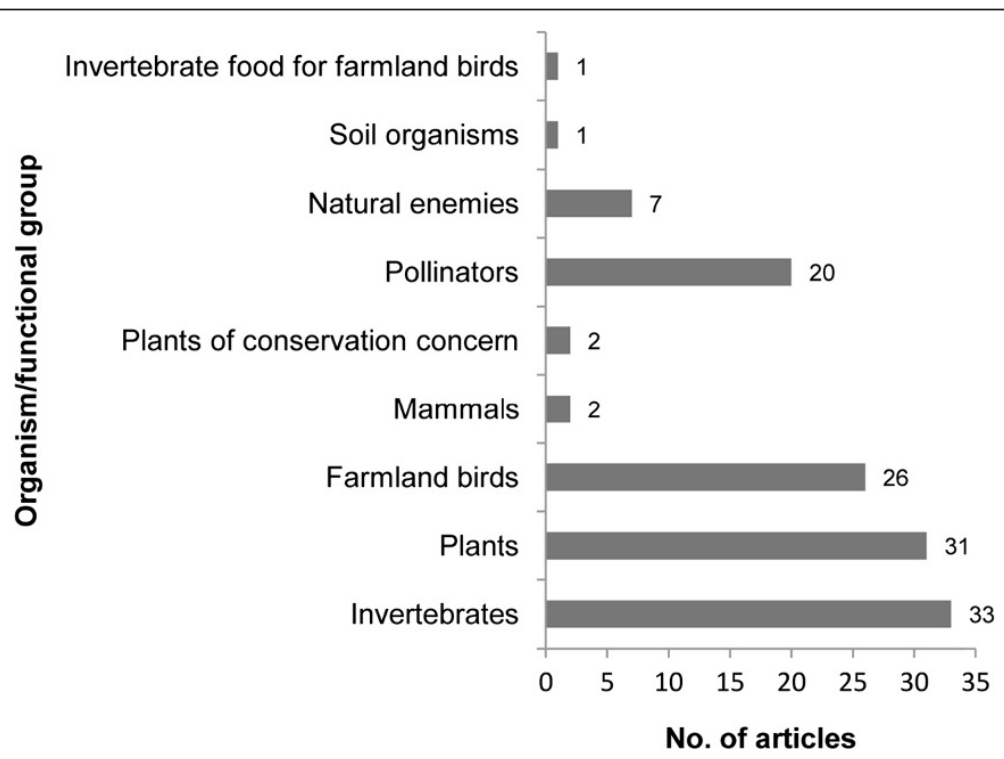

Figure 8 Organism or functional group for agri-environmental investigations. The differences will reflect, at least in part, the search terms used. 


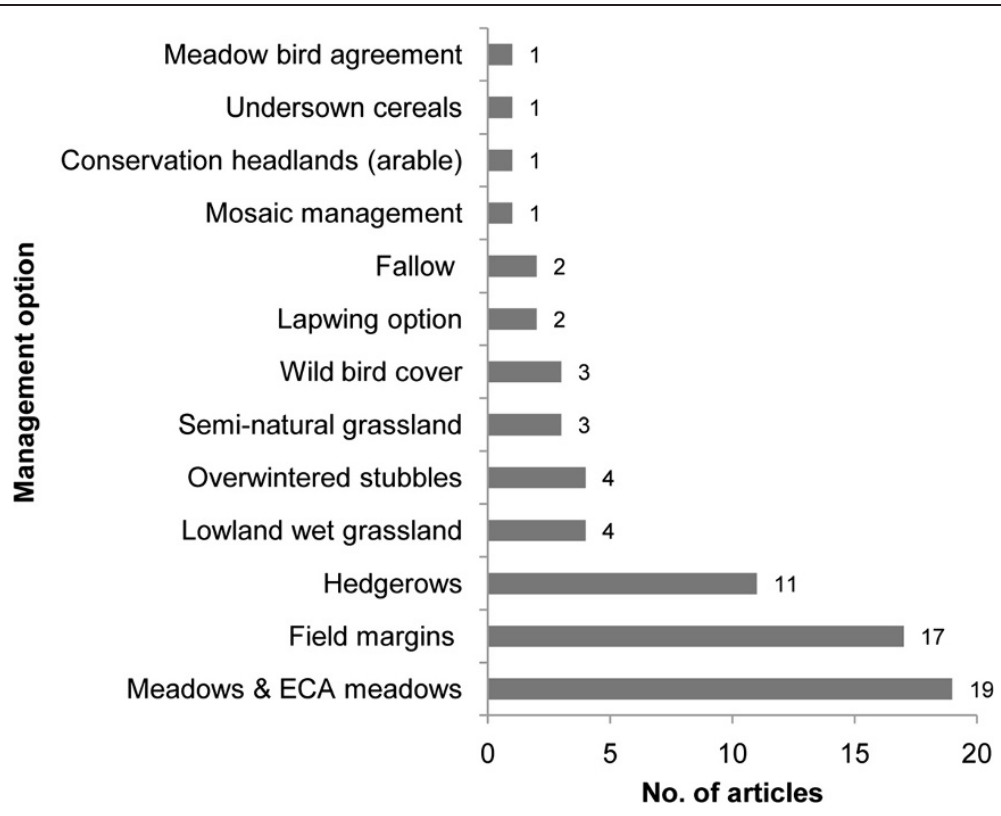

Figure 9 Management options specified in articles where studies investigated farms under agri-environmental schemes.

Some believe they are good indicators of overall biodiversity health, for example butterflies [41].

- Studies of plants and farmland birds were also found in high numbers, even though plants were not specifically searched for. Both are also believed to be good indicators of overall farmland biodiversity health [41]. Furthermore, farmland birds are valued by the public and policy makers.

- There were more studies of pollinators and natural enemies than for soil organisms and invertebrate food for farmland birds.

- Research into the use of field margins as a mitigation measure for biodiversity far outweighed the available research for other biotopes and agrienvironment options.

- In terms of how farming systems impact on biodiversity, organic farming has been studied more often than integrated farming.

\section{Gaps in the research}

- Little research on amphibians and reptiles was found, particularly in studies of agri-environmental schemes. This will partially reflect biases in the search, however, there have been general concerns that these groups have been overlooked in agricultural research [42].

Table 7 Management options investigated on farms under agri-environment agreements and organism studied

\begin{tabular}{|c|c|c|c|}
\hline & Invertebrates & Plants & Farmland birds \\
\hline Meadows (including Swiss ECA meadows) & 11 & 11 & 4 \\
\hline Field margins & 15 & 8 & 1 \\
\hline Hedgerows & 9 & 6 & 2 \\
\hline Lowland wet grassland & 1 & 2 & 2 \\
\hline Overwintered stubbles & 0 & 1 & 3 \\
\hline Semi-improved grassland & 1 & 1 & 2 \\
\hline Wild bird cover (Option for birds UK, France) & 0 & 1 & 2 \\
\hline Lapwing Option (UK option for birds) & 0 & 0 & 2 \\
\hline Fallow & 1 & 1 & 0 \\
\hline Mosaic management (Dutch option for birds) & 0 & 0 & 1 \\
\hline Conservation headlands (unsprayed or unfertilised arable strips) & 0 & 1 & 0 \\
\hline Under-sown cereals & 0 & 1 & 0 \\
\hline Meadow bird agreement (Dutch option for birds) & 0 & 0 & 1 \\
\hline
\end{tabular}

Some options are specific to one region or country and some may no longer exist in the form stated. 


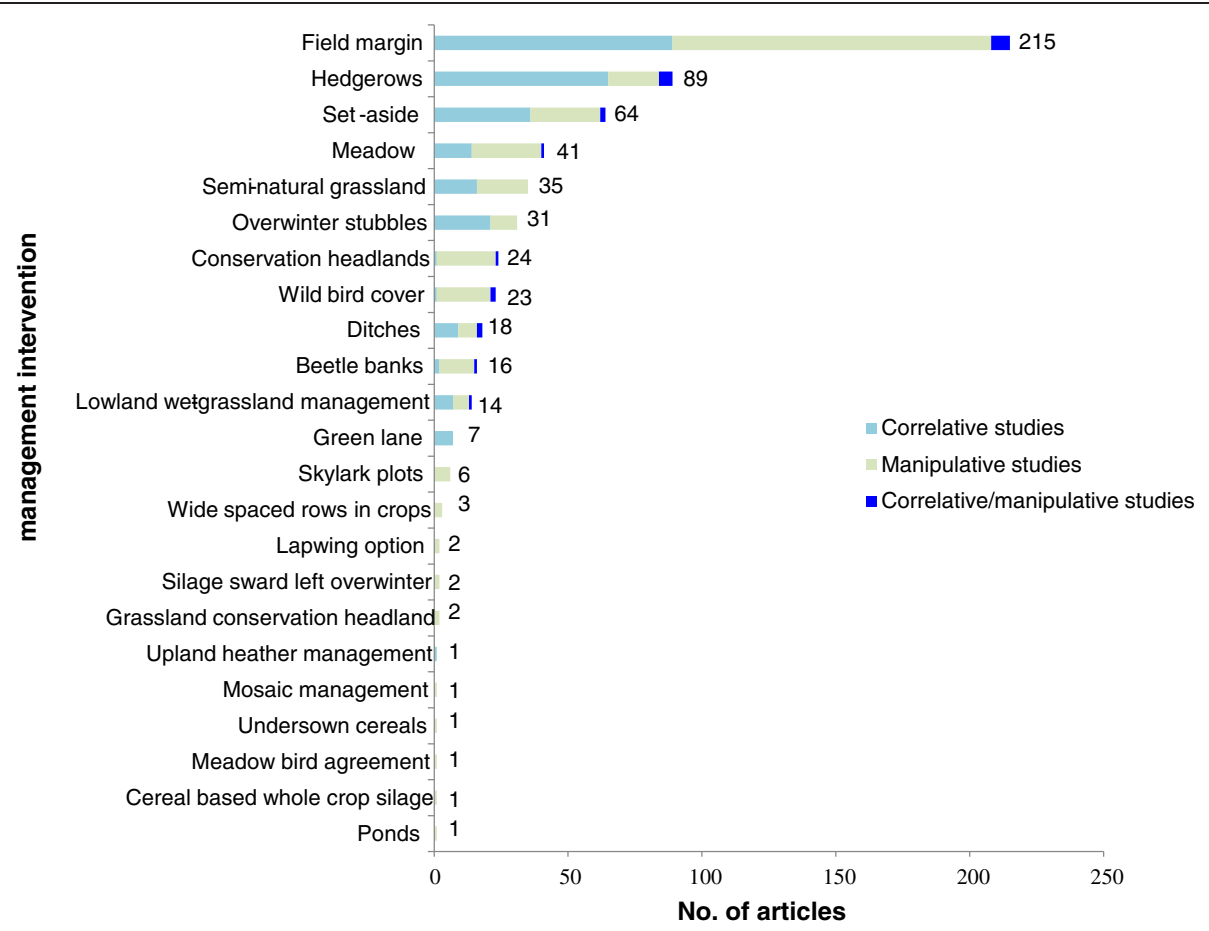

Figure 10 The number of articles reporting the effect of different management interventions on biodiversity. The total number of articles is at the end of each column. For this figure, arable and grass fields are excluded. Fallow studies are included in the set-aside category, riparian buffer strips as part of field margins and the Swiss Ecological Compensation Areas meadows as part of meadow management. Although ponds were excluded from the database, one article is included here as it relates to riparian buffer strips.

- There also appeared to be research gaps for mammals, plants of conservation concern, invertebrate food for farmland birds and soil organisms. Specific literature searches for these organisms would confirm this.

- Some agri-environment scheme options appeared to be more studied than others. For example, conservation headlands, wild bird cover and beetle banks compared with others such as undersown cereals and cereal based whole crop silage. Searching terminology may have biased the findings for some options - 'bird' for example was included as a search term, so may have increased the number of references found for 'wild bird cover'. Variations in local terminology may have also introduced bias. Where more focused information is required, searches for named agri-environment options tailored to the region and time period of interest are recommended.

- Little research comparing the impact of farming system, biotope or agri-environment options on biodiversity was found for Eastern European countries. It may be that Eastern European countries are less likely to publish in English, although this was not tested for.

- There was little research available relating to the impact of integrated farming on biodiversity.
- Further evidence is needed to test the efficacy of agri-environment schemes under different types of farming system. The majority of the research found focused on field margins and organic farming.

\section{Recommendations for further development of the systematic map}

The systematic map is easily updatable. Any updating would provide the opportunity to improve the database.

Recommendations for updating include:

- Examination of the full text of included papers, where possible, in order to confirm coding and categorisation.

- Extension of the database to include additional coding for experimental design and data analysis within papers. This would help facilitate critical appraisal of the included research and also enable more efficient identification of topics suitable for future systematic reviews.

\section{Potential systematic review topics}

The systematic map highlights subtopics that appear to be populated with enough primary research to inform specific systematic reviews. Areas where studies were manipulative rather than correlative may be likely to 
Table 8 Number of articles for each combination of biotope type and taxanomic group

\begin{tabular}{|c|c|c|c|c|c|c|c|c|c|c|c|}
\hline & Invertebrates & Plants & $\begin{array}{l}\text { Farmland } \\
\text { birds }\end{array}$ & Mammals & Reptiles & Amphibians & $\begin{array}{l}\text { Plants of } \\
\text { consconcern } \\
\text { plants }\end{array}$ & Pollinators & $\begin{array}{l}\text { Natural } \\
\text { enemies }\end{array}$ & $\begin{array}{l}\text { Soil } \\
\text { s organisms }\end{array}$ & $\begin{array}{l}\text { Invertebrate } \\
\text { food for } \\
\text { farmland } \\
\text { birds }\end{array}$ \\
\hline Field margins & 153 & 68 & 29 & 18 & 1 & 2 & 4 & 65 & 46 & 8 & 12 \\
\hline Ponds/pools & 1 & 0 & 1 & 0 & 0 & 1 & 0 & 0 & 0 & 0 & 0 \\
\hline $\begin{array}{l}\text { Semi-natural } \\
\text { grassland }\end{array}$ & 15 & 20 & 9 & 2 & 0 & 0 & 1 & 9 & 2 & 0 & 1 \\
\hline Beetle bank & 11 & 5 & 2 & 2 & 0 & 0 & 0 & 1 & 9 & 0 & 3 \\
\hline Hedgerows & 41 & 32 & 27 & 10 & 0 & 0 & 0 & 8 & 9 & 3 & 3 \\
\hline $\begin{array}{l}\text { Grassland } \\
\text { conservation } \\
\text { headland }\end{array}$ & 2 & 2 & 1 & 0 & 0 & 0 & 0 & 0 & 0 & 0 & 1 \\
\hline Set-aside & 32 & 18 & 26 & 7 & 0 & 0 & 3 & 11 & 6 & 2 & 7 \\
\hline $\begin{array}{l}\text { Lowland wet } \\
\text { grassland }\end{array}$ & 4 & 6 & 8 & 0 & 0 & 0 & 0 & 1 & 1 & 1 & 0 \\
\hline Meadows & 20 & 21 & 8 & 1 & 0 & 0 & 0 & 12 & 8 & 0 & 1 \\
\hline Ditches & 6 & 4 & 8 & 1 & 0 & 1 & 0 & 2 & 1 & 1 & 1 \\
\hline $\begin{array}{l}\text { Wild bird } \\
\text { cover }\end{array}$ & 9 & 6 & 17 & 1 & 0 & 0 & 0 & 7 & 0 & 0 & 2 \\
\hline Lapwing option & 0 & 0 & 2 & 0 & 0 & 0 & 0 & 0 & 0 & 0 & 0 \\
\hline $\begin{array}{l}\text { Overwinter } \\
\text { stubbles }\end{array}$ & 3 & 7 & 27 & 0 & 0 & 0 & 0 & 0 & 1 & 1 & 2 \\
\hline $\begin{array}{l}\text { Mosaic } \\
\text { management }\end{array}$ & 0 & 0 & 1 & 0 & 0 & 0 & 0 & 0 & 0 & 0 & 0 \\
\hline $\begin{array}{l}\text { Wide spaced } \\
\text { rows in crops }\end{array}$ & 2 & 2 & 3 & 0 & 0 & 0 & 0 & 0 & 0 & 0 & 1 \\
\hline Skylark plots & 3 & 3 & 5 & 0 & 0 & 0 & 0 & 0 & 0 & 0 & 2 \\
\hline $\begin{array}{l}\text { Cereal based } \\
\text { whole based } \\
\text { silage }\end{array}$ & 1 & 0 & 0 & 0 & 0 & 0 & 0 & 0 & 0 & 0 & 1 \\
\hline $\begin{array}{l}\text { Conservation } \\
\text { headland } \\
\text { (Arable) }\end{array}$ & 15 & 12 & 5 & 1 & 0 & 0 & 3 & 8 & 6 & 0 & 3 \\
\hline $\begin{array}{l}\text { Undersown } \\
\text { cereals }\end{array}$ & 0 & 1 & 0 & 0 & 0 & 0 & 0 & 0 & 0 & 0 & 0 \\
\hline $\begin{array}{l}\text { Silage sward } \\
\text { left } \\
\text { overwinter }\end{array}$ & 1 & 0 & 2 & 0 & 0 & 0 & 0 & 0 & 0 & 0 & 1 \\
\hline $\begin{array}{l}\text { Meadow bird } \\
\text { agreement }\end{array}$ & 0 & 0 & 1 & 0 & 0 & 0 & 0 & 0 & 0 & 0 & 0 \\
\hline Upland heather & 1 & 1 & 0 & 0 & 0 & 0 & 0 & 0 & 0 & 0 & 0 \\
\hline Green lanes & 5 & 5 & 2 & 0 & 0 & 0 & 0 & 3 & 0 & 0 & 0 \\
\hline
\end{tabular}

yield the most robust data for meta-analysis, although critical evaluation of the primary research papers would confirm this.

Invertebrates were the most commonly studied type of organism, with over $50 \%$ of studies manipulative. Pollinators (particularly Lepidoptera and Bombus spp.) and natural enemies (particularly arachnids and carabids) were the most frequently studied invertebrates, and abundance was the measure of outcome most frequently mentioned. Questions investigating which interventions affect the abundance of these invertebrates would be suitable for systematic review. Plants were also highly studied and tended to include data from manipulative experiments, although in some cases plants were used as a comparator for invertebrate abundance studies. There were large numbers of bird studies, but many were correlative and this would need to be taken into account in further analysis. 
Table 9 Number of articles for each type of biotope in different farming systems

\begin{tabular}{|c|c|c|c|c|c|c|c|c|}
\hline & Field margins & Hedgerows & $\begin{array}{l}\text { Semi-natural } \\
\text { grassland }\end{array}$ & Meadows & Ditches & Stubbles & $\begin{array}{l}\text { Conservation } \\
\text { headlands } \\
\text { (arable) }\end{array}$ & Set-aside \\
\hline Organic & $26\left(\begin{array}{lll}4 & 22 & 0\end{array}\right)$ & $9(261)$ & $2\left(\begin{array}{lll}0 & 2 & 0\end{array}\right)$ & $2\left(\begin{array}{lll}1 & 1 & 0\end{array}\right)$ & $2\left(\begin{array}{lll}0 & 1 & 1\end{array}\right)$ & $3\left(\begin{array}{lll}1 & 2 & 0\end{array}\right)$ & 0 & $4(040)$ \\
\hline Conventional & $23\left(\begin{array}{llll}6 & 17 & 0\end{array}\right)$ & $10\left(\begin{array}{lll}2 & 7 & 1\end{array}\right)$ & $2\left(\begin{array}{lll}0 & 2 & 0\end{array}\right)$ & $2\left(\begin{array}{lll}2 & 0 & 0\end{array}\right)$ & $2\left(\begin{array}{lll}0 & 1 & 1\end{array}\right)$ & $2\left(\begin{array}{lll}0 & 2 & 0\end{array}\right)$ & $2\left(\begin{array}{lll}2 & 0 & 0\end{array}\right)$ & $4\left(\begin{array}{lll}1 & 3 & 0\end{array}\right)$ \\
\hline Integrated & $6\left(\begin{array}{lll}3 & 3 & 0\end{array}\right)$ & $3\left(\begin{array}{lll}0 & 3 & 0\end{array}\right)$ & 0 & $1\left(\begin{array}{lll}0 & 1 & 0\end{array}\right)$ & 0 & $1\left(\begin{array}{lll}1 & 0 & 0\end{array}\right)$ & $1\left(\begin{array}{lll}1 & 0 & 0\end{array}\right)$ & $1\left(\begin{array}{lll}0 & 1 & 0\end{array}\right)$ \\
\hline Organic vs conventional & $18\left(\begin{array}{llll}2 & 16 & 0\end{array}\right)$ & $7\left(\begin{array}{lll}2 & 4 & 1\end{array}\right)$ & $2\left(\begin{array}{lll}0 & 2 & 0\end{array}\right)$ & $1\left(\begin{array}{lll}1 & 0 & 0\end{array}\right)$ & $2\left(\begin{array}{lll}0 & 1 & 1\end{array}\right)$ & $2\left(\begin{array}{lll}0 & 2 & 0\end{array}\right)$ & 0 & $2\left(\begin{array}{lll}0 & 2 & 0\end{array}\right)$ \\
\hline $\begin{array}{l}\text { Organic vs conventional } \\
\text { vs integrated }\end{array}$ & $1\left(\begin{array}{lll}0 & 1 & 0\end{array}\right)$ & $1\left(\begin{array}{lll}0 & 1 & 0\end{array}\right)$ & 0 & 0 & 0 & 0 & 0 & 0 \\
\hline Integrated vs conventional & $2\left(\begin{array}{lll}2 & 0 & 0\end{array}\right)$ & $1\left(\begin{array}{lll}0 & 1 & 0\end{array}\right)$ & 0 & 0 & 0 & 0 & $1\left(\begin{array}{lll}1 & 0 & 0\end{array}\right)$ & 0 \\
\hline Organic vs integrated & $2\left(\begin{array}{lll}0 & 2 & 0\end{array}\right)$ & $1\left(\begin{array}{lll}0 & 1 & 0\end{array}\right)$ & 0 & $1\left(\begin{array}{lll}0 & 1 & 0\end{array}\right)$ & 0 & $1\left(\begin{array}{lll}1 & 0 & 0\end{array}\right)$ & 0 & 0 \\
\hline
\end{tabular}

The number of manipulative, correlative and combined articles respectively is in brackets. Where a study compared farming systems for example 'organic versus conventional', the study was also listed as 'organic' and 'conventional'.

Field margins were the most commonly studied biotope, with $50 \%$ of the studies manipulative, and the majority of field margin experiments also investigating invertebrates.

Specific systematic review questions that are likely to yield data suitable for meta-analysis may include:

'What is the comparative effectiveness of field margin management interventions ( $\mathrm{X}, \mathrm{Y}$ and $\mathrm{Z}$ ) for enhancing invertebrate abundance?'

Or more specifically

'What is the comparative effectiveness of field margin flower mixtures for enhancing pollinator abundance?'

Other areas that, although less highly populated with papers, may still enable systematic review analysis could include investigations into the impacts of ploughing and other tillage on invertebrates, and the impacts of grazing intensity on invertebrates. Comparisons of farming system were less frequent and appeared to be disparate - possibly making these questions less suitable for further analysis.

\section{Limitations of the systematic map}

The high volume of this literature found in this exercise demonstrates the size of this topic. Time, manpower and financial constraints precluded study of the full texts. The broad topic also complicated compilation of the database.

\section{Limitations during searching}

- Invertebrates and farmland birds were specified in the search terms as indicators of biodiversity at the request of the stakeholders. Amphibians, reptiles, mammals, and plants were not, but were still included in the systematic map database where found.

- The databases used in the searching phase, document publications starting after a particular date/year, so the results will not include a comprehensive assessment of earlier articles.

- The search was limited to literature published in English, and some of the databases were compiled for UK usage. This will have resulted in an international bias.

\section{Limitations during the exclusion phase}

- Exclusion of references was based upon the abstract only, due to the volume of literature captured, and

Table 10 Number of articles for each type of organism on field margins in different farming systems

\begin{tabular}{|c|c|c|c|c|c|c|c|c|c|}
\hline & Invertebrates & Plants & $\begin{array}{l}\text { Farmland } \\
\text { birds }\end{array}$ & Mammals & $\begin{array}{l}\text { Plants of } \\
\text { cons } \\
\text { concern }\end{array}$ & Pollinators & $\begin{array}{l}\text { Natural } \\
\text { enemies }\end{array}$ & $\begin{array}{l}\text { Soil } \\
\text { organisms }\end{array}$ & $\begin{array}{l}\text { Invertebrate } \\
\text { food for } \\
\text { farmland } \\
\text { birds }\end{array}$ \\
\hline Organic & 19 & 8 & 2 & 2 & 1 & 9 & 6 & 0 & 2 \\
\hline Conventional & 15 & 5 & 1 & 3 & 1 & 7 & 5 & 1 & 3 \\
\hline Integrated & 5 & 0 & 1 & 2 & 0 & 1 & 3 & 1 & 1 \\
\hline Organic vs conventional & 12 & 5 & 1 & 1 & 1 & 6 & 2 & 0 & 2 \\
\hline $\begin{array}{l}\text { Organic vs conventional vs } \\
\text { integrated }\end{array}$ & 0 & 0 & 0 & 1 & 0 & 0 & 0 & 0 & 0 \\
\hline Integrated vs conventional & 2 & 0 & 0 & 0 & 0 & 1 & 2 & 0 & 1 \\
\hline Organic vs integrated & 2 & 0 & 0 & 0 & 0 & 0 & 1 & 0 & 0 \\
\hline
\end{tabular}

Where a study compared farming systems for example 'organic versus conventional', the article was also listed as 'organic' and 'conventional' separately. 
Table 11 Number of articles for each type of organism for hedgerows in different farming systems

\begin{tabular}{|c|c|c|c|c|c|c|c|c|}
\hline & Invertebrates & Plants & $\begin{array}{l}\text { Farmland } \\
\text { birds }\end{array}$ & Mammals & Pollinators & $\begin{array}{l}\text { Natural } \\
\text { enemies }\end{array}$ & $\begin{array}{l}\text { Soil } \\
\text { organisms }\end{array}$ & $\begin{array}{l}\text { Invertebrate } \\
\text { food for } \\
\text { farmland birds }\end{array}$ \\
\hline Organic & 3 & 5 & 1 & 1 & 0 & 1 & 1 & 0 \\
\hline Conventional & 2 & 6 & 2 & 1 & 0 & 0 & 1 & 0 \\
\hline Integrated & 2 & 0 & 1 & 0 & 0 & 1 & 1 & 0 \\
\hline Organic vs conventional & 1 & 5 & 1 & 1 & 0 & 0 & 0 & 0 \\
\hline $\begin{array}{l}\text { Organic vs conventional } \\
\text { vs integrated }\end{array}$ & 1 & 0 & 0 & 0 & 0 & 0 & 1 & 0 \\
\hline Integrated vs conventional & 0 & 0 & 1 & 0 & 0 & 0 & 0 & 0 \\
\hline Organic vs integrated & 1 & 0 & 0 & 0 & 0 & 1 & 0 & 0 \\
\hline
\end{tabular}

Where a study compared farming systems for example 'organic versus conventional', the article was also listed as 'organic' and 'conventional'.

so depended upon the detail provided. Some important information will be missing, and other information may be misleading.

\section{Limitations in interpretation}

- Counting studies may imply either that there is an 'evidence gap', or that there is a large amount of research for a subtopic, but does not consider the quality and robustness of studies and so could be misleading (i.e. a small quality of high quality studies will provide more robust evidence than a large number of low quality studies.)

- As no quality appraisal of research has taken place in this systematic map, we have deliberately not indicated whether individual studies reported a positive or negative impact of interventions on the studied outcome (i.e. biodiversity). Users of the map are advised to read the papers relevant to the intervention or organism of interest in order to assess their quality and robustness.

- Ponds were excluded (the one reference to ponds was included because riparian buffer strips were also studied). This will have affected the number of wetland taxa studies included.

- There may appear to be research gaps for some topic areas due to incomplete reporting within the abstracts of included studies.

- The summary statistics report the number of articles rather than the number of studies for each topic area. This may bias the number of results found in favour of those with multiple outputs of one study.

- Coding of each study was carried out independently for each factor. For some factors, false relationships will be indicated. For example, where a study investigated more than one biotope, specific management options will show for all biotopes investigated (e.g. cutting of field margins may be specific to them, but if other biotopes such as hedgerows were included in the same study, the independent coding would imply that cutting was also studied for hedgerows.)

- Keywording should accurately reflect the range of topics in the field. However, names for interventions, such as agri-environment scheme options, have changed historically, and vary between regions and schemes. This should be taken into consideration when searching the database.

\section{Conclusions}

This systematic map provides a large database of research on the primary topic: 'The effectiveness of Integrated Farm Management, Organic farming and Agri-environment Schemes as interventions for conserving biodiversity in temperate Europe, with an emphasis on birds and invertebrates', subject to the limitations described. The map is upto-date to June 2010 (with the exception of the Conservation Evidence search carried out in September 2010).

More studies were included in the final map than would have been in a systematic review, but full data extraction and critical evaluation of the included papers was not carried out. Papers are listed as either correlative or manipulative, and where available, basic experimental design is also shown in the database. Beyond this there is no indication of the quality of the papers.

\section{Implications for policy and management}

The map provides a research tool for users interested in this topic area. It can be used to gather information on a wide array of sub-topics that can be cross-tabulated. As the map does not include quality appraisal or data synthesis of studies, users should retrieve the full text copies of studies of interest in order to assess them fully.

\section{Implications for future farmland biodiversity research}

The systematic map highlights a variety of areas for which there appear to be evidence gaps. Some potential questions to be investigated by further primary research include: 
'How effective are agri-environment options in providing for amphibians and reptiles?'

'How effective are agri-environment schemes under differing farming systems?'

It would also be useful for more research to investigate the impacts of farming interventions on biodiversity in Eastern European countries, as research appeared to be generally lacking for these regions.

\section{Implications for future systematic maps}

This systematic map was one of the first of its kind in environmental management and a number of implications for future systematic maps in the field have arisen. Systematic maps have the ability to provide a useful tool to investigate wider topic areas than systematic review, and potential to include non-experimental evidence. For example, in this case we have included correlative studies that may not be suitable for systematic review analysis. It may also be feasible to include in systematic maps, research that, for example, investigates the costs of interventions, where this may be of use to decision makers. In order to make systematic maps more robust for the future, it may be usful to include ways in which to critically evaluate studies. As this study has illustrated, questions that are too broad or disparate can cause issues of repeatability with systematic maps as well as with systematic reviews.

As systematic mapping for environmental evidence is new, different approaches are likely to be used by different authors. A Systematic Mapping Methods group hosted by the Collaboration for Environmental Evidence has been established to evaluate their use in the evidence-based framework for ecology and conservation, and will attempt to deal with some of the issues that have arisen.

\section{Additional files}

Additional file 1: Operational definitions and clarification of terms.
Additional file 2: Coding categories employed in the systematic
map database.
Additional file 3: Database of farmland biodiversity research
searchable by subtopic.
Additional file 4: How to search the database.
Additional file 5: Record of searches.
Additional file 6: References included in the systematic map
database.
Additional file 7: Systematic reviews and meta-analyises of
relevance.

\section{Competing interests}

The authors declare that they have no competing interests.

\section{Authors' contributions}

NPR designed the study, and carried out the 2008 searches and sorting. KLJ carried out the 2010 searches and sorting. Both authors worked on the systematic map design and coding and on the manuscript. Both authors read and approved the final manuscript.

\section{Acknowledgements}

$\mathrm{KLJ}$ was funded by the John Oldacre Foundation. Stakeholder meetings, training and some consumable costs were funded by a British Ecological Society-Ecology into Policy Grant.

Received: 14 January 2012 Accepted: 14 February 2012 Published: 1 May 2012

\section{References}

1. Robinson RA, Sutherland WJ: Post-war changes in arable farming and biodiversity in Great Britain. Journal of Applied Ecology 2002, 39:157-176.

2. The reform of the CAP towards 2020: Consultation Document for Impact Assessment. Brussells: European Commission; 2010.

3. Donald PF, Green RF, Heath MF: Agricultural intensification and the collapse of Europe's farmland bird populations. Proceedings Royal Society London Ser. B 2001, 268:25-29.

4. Fuller RJ, Gregory RD, Gibbons DW, Marchant JH, Wilson JD, Baillie SR, Carter $\mathrm{N}$ : Population declines and range contractions among lowland farmland birds in Britain. Conservation Biology 1995, 9:1425-1441.

5. Sotherton NW, Self MJ: Changes in plant and arthropod diversity on lowland farmland: an overview. In The Ecology and Conservation of Lowland Farmland Birds. Edited by Aebischer NJ, Evans AD, Grice PV, Vickery JA. Southampton: British Ornithologists' Union; 2000:26-35. 27-28 March 1999.

6. Flowerdew JR: Mammal biodiversity in agricultural habitats. In Biodiversity and Conservation in Agriculture. Edited by Kirkwood RC. UK: British Crop Protection Council; 1997:25-40.

7. Boatman ND, Parry HR, Bishop JD, Cuthbertson AGS: Impacts of Agricultural Change on Farmland Biodiversity in the UK. In Issues in Environmental Science and Technology. No.25. Biodiversity under Threat. Edited by Hester RE, Harrison RM. Cambridge UK: Royal Society of Chemistry; 2007:1-32.

8. Boatman ND: How do farming practices influence biodiversity? In Farming, Forestry and the Natural Heritage: Towards a More Integrated Future. Edited by Davidson R, Galbraith C. Edinburgh: Scottish Natural Heritage; 2006:39-57.

9. Benton TG, Vickery JA, Wilson JD: Farmland biodiversity: is habitat heterogeneity the key? Trends in Ecology and Evolution 2003, 18:182-188.

10. Pretty J, Sutherland WJ, Ashby J, Auburn J, Baulcombe D, Bell M, Bentley J, Bickersteth S, Brown K, Burke J, Campbell H, Chen K, Crowley E, Crute I, Dobbelaere D, Edwards-Jones G, Funes-Monzote F, Godfray HCJ, Griffon M, Gypmantisiri P, Haddad L, Halavatau S, Herren H, Holderness M, Izac A-M, Jones M, Koohafkan P, Lal R, Lang T, McNeely J, et al: The top 100 questions of importance to the future of global agriculture. International Journal of Agricultural Sustainability 2010, 8(4):219-236.

11. Commission of the European Communities: Perspectives for the Common Agricultural Policy. Brussels: COM, 85; 1985:333.

12. Kleijn D, Sutherland WJ: How effective are European agri-environment schemes in conserving and promoting biodiversity? Journal of Applied Ecology 2003, 40:947-969.

13. European Court of Auditors: Is Agri-environment support well designed and managed? Special report no.7//2011. Luxembourg: European Court of Auditors; 2011

14. Kleijn D, Baquero RA, Clough Y, Diaz M, Esteban J, Fernadez F, Gabriel D, Herzog F, Holzshuh A, Johl R, Knop E, Kruess A, Marshall EJP, Steffan-Dewenter I, Tscharntke T, Verhulst J, West TM, Yela JL: Mixed biodiversity benefits of agri-environment schemes in five European countries. Ecology Letters 2006, 9(3):243-254.

15. Wittingham MJ: Will agri-environment schemes deliver substantial biodiversity gain, and if not why not? Journal of Applied Ecology 2007, 44(1):1-5.

16. Marshall EPJ, West TM, Kleijn D: Impacts of agri-environment field margin prescriptions on the flora and fauna of arable farmland in different landscapes. Agriculture, Ecosystems and Environment 2005, 113:36-44.

17. Berry P, Ogilvy S, Gardner S: Integrated Farming and Biodiversity - English Nature Research Reports no. 634. Adas: English Nature; 2005. 
18. Wickramasinghe $L P$, Harris $S$, Jones $G$, Vaughan N: Bat activity and species richness on organic and conventional farms: impact of agricultural intensification. Journal of Applied Ecology 2003, 40(6):984-993.

19. Chapple DG, Wade DR, Laverick RM, Eldridge PJ: Whole farm integrated management and farmland birds. Aspect of Applied Biology 2002, 67:129-134.

20. Feber RE, Smith H, Macdonald DW: The effects on butterfly abundance of the management of uncropped edges of arable fields. Journal of Applied Ecology 1996, 33(5):1191-1205.

21. Hole DG, Perkins AJ, Wilson JD, Alexander IH, Grice PV, Evan AD: Does organic farming benefit biodiversity? Biological Conservation 2005, 122:113-130.

22. Bengtsson J, Ahnstrom J, Weibull AC: The effects of organic agriculture on biodiversity and abundance: a meta-analysis. Journal of Applied Ecology 2005, 42(2):261-269.

23. Fuller RJ, Norton LR, Feber RE, Johnston PJ, Chamberlain DE, Joys AC, Mathews F, Stuart R, Townsend MC, Manley WJ, Wolfe MS, MacDonald DW Firbank LG: Benefits of organic farming to biodiversity vary among taxa. Biology Letters 2005, 1(4):431-434.

24. Gabriel D, Sait SM, Hodgson JA, Schmutz U, Kunin WE, Benton TG: Scale matters: the impact of organic farming on biodiversity at different spatial scales. Ecology Letters 2010, 13(7):858-869.

25. Coren E, Fisher M: The conduct of systematic research reviews for SCIE knowledge reviews. UK: Social Care Institute for Excellence; 2006. www.scie. org.uk.

26. Grant MJ, Booth A: A typology of reviews: an analysis of 14 review types and associated methodologies. Health Information and Libraries Journal 2009, 26:91-108

27. Clapton J, Rutter D, Sharif N: SCIE Systematic mapping guidance. April 2009. UK: Social Care Institute for Excellence; 2009. www.scie.org.uk/publications/ researchresources/rr03.pdf.

28. Bates S, Clapton J, Coren E: Systematic maps to support the evidence base in social care. Evidence and Policy 2007, 3(4):539-551.

29. Sutherland WJ, Armstrong-Brown S, Armsworth PR, Brereton T, Brickland J, Campbell CD, Chamberlain DE, Cooke Al, Dulvy NK, Dusic NR, Fitton M, Freckleton RP, Godfrey CJ, Grout N, Harvey HJ, Heldley C, Hopkins JJ, Kift NB, Kirby J, Kunin WE, MacDonald DW, Marker B, Naura M, Neale AR, Oliver T, Osborn D, Pullin AS, Shardlow MEA, Showler DA, Smith PL, et al: The identification of 100 ecological questions of high policy relevance in the UK. Journal of Applied Ecology 2006, 43:617-627.

30. Bradbury RB, Browne SJ, Stevens DK, Aebischer NJ: Five-year evaluation of the impact of the Arable Stewardship Pilot Scheme on birds. Ibis 2004, 146(2):171-180

31. Collaboration for Environmental Evidence: Guidelines for Systematic Review in Environmental Management. Version 4.0. Environmental Evidence 2010.: ; www.environmental evidence.org/Authors.htm/Guidelines.pdf.

32. Karla N, Newman M, Karla N, Newman M: A systematic map of the research on the relationship between Obeisity and Sedentary Behaviour in young people. Technical report. In Research Evidence in Education Library. London: EPPI-Centre, Social Science Research Unit, Institute of Education, University of London; 2009 .

33. Sharif N, Brown W, Rutter D: Systematic Map Report 03. The extent and impact of depression on BME older people and the acceptability, accessibility and effectiveness of social care provision. University of London: Social Care Institute for Excellence. Social Science Research Unit, Institute of Education 2008.

34. Feber RE, Johnson PJ, Firbank LG, Hopkins A, Macdonald DW: A comparison of butterfly populations on organically and conventionally managed farmland. Journal of Zoology 2007, 273(1):30-39.

35. Irmler U: Changes in earthworm populations during conversion from conventional to organic farming. Agriculture, Ecosystems \& Environment 2010, 135(3):194-198.

36. Feber RE, Hopkins A: Diversity of plant and butterfly species on organic farmland field margins in relation to management. In British Grassland Society Fifth Research Conference: 8-10 September 1997. UK: University of Plymouth; 1997:63-64.

37. Pfiffner L, Niggli U: Effects of bio-dynamic, organic and conventional farming on ground beetles (Col Carabidae) and other epigaeic arthropods in winter wheat. Biological Agriculture \& Horticulture 1996, 12(4):353-364
38. Hutcheon JA, lles DR, Kendall DA: Earthworm populations in conventional and integrated farming systems in the LIFE Project (SW England) in 1990-2000. Annals of Applied Biology 2001, 139(3):361-372.

39. Pywell RF, Meek WM, Carvell C, Hulmes L: The SAFFIE project: enhancing the value of arable field margins for pollinating insects. Association of Applied Biologists 2007, 81:239-245.

40. Alvarez T, Frampton GK, Goulson D: Epigeic Collembola in winter wheat under organic, integrated and conventional farm management regimes. Agriculture, Ecosystems \& Environment 2001, 83(1/2):95-110.

41. Department for Food and Rural Affairs: UK Biodiversity Indicators in your Pocket 2010. Measuring progress towards halting biodiversity loss PB13400. UK: Defra; 2010

42. ADAS: Hedgerow Management and Wildlife Review: further update, edit and publication. Final Report for UK Department of Food and Rural Affairs (BD2108). UK: Defra; 2004

doi:10.1186/2047-2382-1-4

Cite this article as: Randall and James: The effectiveness of integrated farm management, organic farming and agri-environment schemes for conserving biodiversity in temperate Europe - A systematic map. Environmental Evidence 2012 1:4.

\section{Submit your next manuscript to BioMed Central and take full advantage of:}

- Convenient online submission

- Thorough peer review

- No space constraints or color figure charges

- Immediate publication on acceptance

- Inclusion in PubMed, CAS, Scopus and Google Scholar

- Research which is freely available for redistribution

Submit your manuscript at www.biomedcentral.com/submit
C BioMed Central 